\section{Sewage Bacteria Bed Fauna in its Natural Setting}

IT has been observed that the bacteria beds of sewage works form an environment for insects unlike anything in Nature'. The depth of the habitable zone is great, so that compared with most insect habitats it is almost like the cube against the square. It is well aerated and constantly supplied with a basic food supply both in solution and in finely divided form evenly spread over the bed. The temperature is protected from extremes, on one hand by the heat generated by vital processes and on the other hand by the effects of evaporation. The daily temperature swing is restricted. Larvæ and pupæ are not accessible to birds except at the surface. This insect fauna is characterized by the small number of successful species and the great prevalence of those few which do succeed. In eight years of trapping on the Knostrop beds at Leeds, more than half a million insects were caught and scrutinized; and, though in all about a hundred species were taken, $99 \cdot 7$ per cent of the total belonged to six species of nematocerous flies, namely, Metriocnemus longitarsus, $M$. hirticollis, Spaniotoma minima, S. perennis, Psychoda alternata and $P$. severini. The enchytraeid worm, Lumbricillus lineatus, has an abundance equal to, or perhaps surpassing, that of any of these larva in the Knostrop beds. At some works, though not at Leeds, Psychoda cinerea and Anisopus cinctus show a similar prevalence. The collembolan Achorutes viaticus and the cordylurid fly Spathiophora hydromyzina are the only other insects so far recorded as prevalent in the beds.

I have recently located this fauna almost intact, though mingled with a number of other successful forms, in the natural setting of a mud flat about four miles from the nearest sewage works. A small, slightly contaminated stream passes under a bridge and, as an effect of an eddy, forms a mud flat about thirty yards long and fifteen yards wide with a surface usually an inch or two above water level. It is constantly water-logged through seepage, but is rarely flooded and then only for brief periods after heavy rainstorms, for there is a sill a short distance downstream giving a rapid recovery to normal level. It is overhung by trees and receives in autumn a thick carpet of leaves which is absorbed into the mud in winter and largely disintegrated by summer. Samples of the surface mud taken to the laboratory have yielded 1,500 insects, of which 44 per cent belong to eight of the ten species enumerated above as forming the insect fauna of the bacteria beds, Achorutes and Spathiophora only having not appeared in the cultures. Of the others emerging, $3 \mathrm{I}$ per cent is shared equally between the bloodsucking genus Culicoides and the short-palped craneflies, Limoniinæ, both of which have very rarely appeared in collections from the bacteria beds. The characteristic enchytraeid worm of the sewage bed, $L$. lineatus, also occurs in the mud flat, but in num. bers is almost masked by a swarming tubificid worm densely clustered just below the surface.

Thus it appears that the macrofauna of the bacteria bed is derived from that of the organic mud flat, but the two types of environment are not much alike. The mud flat, however, does rather resemble the sand sewage filter. In this a bed of porous sand some four feet deep is flooded at frequent intervals with settled sewage which seeps through and is purified in passage. A mat of cellulose and other débris forms on the surface, and when this has thickened and dried it can be rolled off like a carpet, leaving the filter again porous and receptive to further dosing.

This discovery of the bacteria bed fauna in its natural setting should help in the study of its theoretical aspects which hold much of interest, especially in regard to animal competition ${ }^{2,3,4}$. It is also of practical interest since the invasion of dwellings by sewage flies is often a matter of concern to sanitary authorities and it is important to know from what other sources they may come.

The University,

Leeds, 2. Aug. 16.

${ }^{1}$ Dyson, J. E., and Lloyd, Ll., J. Proc. Inst. Sewage Purification, Pt. 2, 28 '(1933).

'Lloyd, Ll., Graham, J. F., and Reynoldson, T. B., Ann. App. Biol., 27,122 (1940).

${ }^{3}$ Lloyd, Ll., Ann. App. Biol., 30, 47 (1943)

‘Lloyd, Ll., Ann. App. Biol., 30, 358 (1943).

\section{Imperial Forestry Institute, Oxford}

Is commenting in Nature of July 15, p. 94 on the 1942-43 report of the Imperial Forestry Institute, it is stated that there is difficulty in distinguishing between the respective parts played by the Imperial Forestry Institute and the University Department or School of Forestry. This is simply explained by the fact, set out at length in the 1937-38 report, that in 1938 they became a single organization supported jointly by the Colonies, the Forestry Commission, the University of Oxford and a few smaller contributors. At the same time, the information branch of the Institute was taken over by the Imperial Agricultural Bureaux to constitute a new Imperial Forestry Bureau which still works in close collaboration with the Institute. This latter change resulted in a transfer to the Bureaux of nearly all the original Dominion support for the Institute, leaving the Colonial Empire in a still more predominant position among the supporters of the Institute.

The amalgamation of School and Institute was made primarily for administrative reasons and to fit in with the new arrangements for the training of officers for the Colonial Forest Service; it did not affect the research work being done by the staff. This latter work continues to be directed towards Empire needs and interests so far as is possible in Great Britain. In several fields, however, for example sylviculture, there is not a great deal having a direct bearing on Empire forestry that can be done in Britain. Research in these subjects is accordingly directed more towards fundamental problems and problems representative of types likely to occur anywhere, and it has to be carried out in the woods and forests accessible from Oxford. Such studies are clearly likely to be more productive and useful if undertaken in co-operation with the related research activities of the Forestry Commission.

From the educational point of view, it is essential, for keeping the teaching live and practical, that the staff should be in the closest possible touch with current practice and developments where the teaching is done. Moreover, the Forestry Commission looks to Oxford, as having the only University Forestry School in England, to play its part and undertake its share in forestry education for service at home as well as abroad, and in forestry research of a fundamental nature. It was for these reasons that 